\title{
Expression of lipid metabolism-related proteins in breast phyllodes tumors
}

\author{
Y. Y. JUNG, Y. K. LEE, J. S. KOO* \\ Department of Pathology, Yonsei University College of Medicine, Seoul, South Korea \\ *Correspondence: kjs1976@yuhs.ac
}

Received July 15, 2015 / Accepted September 7, 2015

\begin{abstract}
The aim of this study was to investigate the expression of lipid metabolism-related proteins and the implications thereof in phyllodes tumor (PT) of the breast. A tissue microarray (TMA) was constructed using paraffin blocks from 194 PT patient tissue samples. Immunohistochemical staining for lipid metabolism-related proteins, namely hormone-sensitive lipase (HSL), perilipin 2, fatty-acid-binding proteins 4 (FABP4), carnitine palmitoyltransferase-1 (CPT-1), acyl-CoA oxidase 1 (ACOX-1), and fatty acid synthase (FASN) was performed, and the immunohistochemical staining results were analyzed with respect to clinicopathologic parameters. The numbers of benign, borderline, and malignant PTs were 151, 27, and 16, respectively. The expression of HSL, perilipin 2, FABP4, CPT-1, and FASN in stromal components was higher in higher grade tumors. On univariate analysis, shorter disease-free survival (DFS) was associated with stromal perilipin 2 positivity $(p<0.001)$ and stromal CPT-1 positivity ( $p=0.004)$. Shorter overall survival (OS) was associated with stromal perilipin 2 positivity $(p<0.001)$, stromal FABP4 positivity $(p<0.001)$, stromal CPT-1 positivity $(p=0.004)$, and stromal FASN positivity $(p<0.001)$. Multivariate Cox analysis revealed that stromal perilipin 2 positivity (hazard ratio $=31.693,95 \%$ CI: $1.341-748.8, p=0.032$ ) was an independent factor for shorter DFS. In conclusion, higher expressions of HSL, perilipin 2, FABP4, CPT-1 and FASN in the stromal component were observed in higher grade PT.
\end{abstract}

Key words: lipid, metabolism, phyllodes tumor

Phyllodes tumor (PT) is a relatively rare tumor that accounts for $0.3-1.5 \%$ of breast neoplasms. Because it shares morphologic characteristics with another fibroepithelial tumor, fibroadenoma, and because PT can have histologically heterogeneous features within a given tumor, it is sometimes difficult for definitive diagnosis $[1,2]$. In addition, phyllodes tumor may manifest as a clinically malignant tumor, showing recurrence or hematogenous metastasis [3]. In histologic classification, although there are discrepancies among classification schemes, it is classified into 3 categories; benign, borderline, or malignant, using World Health Organization

\footnotetext{
Abbreviations: PT - phyllodes tumor; WHO - World Health Organization; TCA - tricarboxylic acid; HSL - hormone-sensitive lipase; FABP - fattyacid-binding proteins; CPT - Carnitine palmitoyltransferase; ACOX1 - acylCoA oxidase 1; CAIX - Carbonic anhydrase IX; MCT4 - Monocarboxylate transporter 4; H\&E - hematoxylin and eosin; FASN - fatty acid synthase; EMT - epithelial-mesenchymal transition; PKM2 - pyruvate kinase muscle isozyme 2; TGIF2, TGFB-Induced Factor Homeobox 2, ALDH - aldehyde dehydrogenase; GD2 - disialoganglioside
}

(WHO) classification standards. High grade PTs display tumor aggressive features, such as tumor recurrence and distant metastasis.

Tumor cells produce energy by aerobic glycolysis, while normal cells do so by aerobic phosphorylation through the tricarboxylic acid (TCA) cycle, a phenomenon called the Warburg effect [4]. Glycolysis is an important element of cancer metabolism, but cancer cell metabolism is not the result of a single metabolic system. Previous studies have reported that the dominant form of metabolism can be glycolysis or oxidative phosphorylation [5], depending on the tumor type. This flexibility of cancer cell metabolic system is a major obstacle to therapies targeting cancer cell metabolism. In addition to glycolysis and mitochondrial metabolism, lipid metabolism is also an element of cancer metabolism. Important components of lipid metabolism include lipolysis, lipid transfer, and $\beta$-oxidation.

The molecules that play important roles in lipolysis include hormone sensitive lipase (HSL), which disassembles 
triglycerides into free fatty acids [6], and perilipin 2, a lipid droplet gate-keeper in lipolysis [7]. The key molecule in the lipid transfer process is fatty-acid-binding protein (FABP), which serves as a free fatty acid transporter [8]. Carnitine palmitoyltransferase-1 (CPT-1) [9] and acyl-CoA oxidase 1 (ACOX1) [10] are known to play key roles in $\beta$-oxidation. In previous studies, higher expression of glycolysis-related proteins, such as Glut-1, carbonic anhydrase IX (CAIX), and MCT4, was found in PTs of higher grade [11], and the expression of serine/glycine metabolism-related proteins was also higher in higher grade PTs [12]. These results suggest that the expression of lipid metabolism-related proteins may also differ according to PT grade, but there has been no study published to date on this issue. Thus, the aim of this study was to investigate the expression of lipid metabolism-related proteins in different grades of PTs, and the clinical implications thereof.
Table 1. Source, clone, and dilution of antibodies employed

\begin{tabular}{llll}
\hline antibody & clone & dilution & company \\
\hline HSL & Polyclonal & $1: 100$ & Abcam, Cambridge, UK \\
Perillipin 2 & Polyclonal & $1: 100$ & Abcam, Cambridge, UK \\
FABP4 & Polyclonal & $1: 100$ & Abcam, Cambridge, UK \\
CPT-1 & 8F6AE9 & $1: 200$ & Abcam, Cambridge, UK \\
Acyl-CoA oxidase 1 & Polyclonal & $1: 50$ & Abcam, Cambridge, UK \\
FASN & Polyclonal & $1: 200$ & Abcam, Cambridge, UK \\
\hline
\end{tabular}

\section{Patients and methods}

Patient selection. Tissue samples from patients who underwent surgical resection at Severance Hospital after being diagnosed with PT from 2000 to 2010 were enrolled in this study. The study was approved by the Institutional Review

Table 2. Clinicopathologic characteristics of patients with phyllodes tumor

\begin{tabular}{|c|c|c|c|c|c|}
\hline Parameters & $\begin{array}{c}\text { Total } \\
\mathrm{N}=194 \\
(100 \%)\end{array}$ & $\begin{array}{c}\text { PT, } \\
\text { Benign } \\
\mathrm{N}=151 \\
(100 \%)\end{array}$ & $\begin{array}{l}\text { PT, Borderline } \\
\mathrm{N}=27(100 \%)\end{array}$ & $\begin{array}{l}\text { PT, Malignant } \\
\mathrm{N}=16(100 \%)\end{array}$ & $P$-value \\
\hline Age (years, mean \pm SD) & $40.1 \pm 12.4$ & $38.9 \pm 12.2$ & $42.3 \pm 11.5$ & $47.6 \pm 12.9$ & 0.017 \\
\hline Tumor size $(\mathrm{cm}$, mean $\pm \mathrm{SD})$ & $4.0 \pm 2.6$ & $3.6 \pm 2.2$ & $4.3 \pm 2.5$ & $6.7 \pm 4.6$ & 0.001 \\
\hline Stromal cellularity & & & & & $<0.001$ \\
\hline Mild & $119(61.3)$ & $118(78.1)$ & $1(3.7)$ & $0(0.0)$ & \\
\hline Moderate & $63(32.5)$ & $33(21.9)$ & $23(85.2)$ & $7(43.8)$ & \\
\hline Marked & $12(6.2)$ & $0(0.0)$ & $3(11.1)$ & $9(56.2)$ & \\
\hline Stromal atypia & & & & & $<0.001$ \\
\hline Mild & $154(79.4)$ & $149(98.7)$ & $5(18.5)$ & $0(0.0)$ & \\
\hline Moderate & $30(15.5)$ & $2(1.3)$ & $20(74.1)$ & $8(50.0)$ & \\
\hline Marked & $10(5.2)$ & $0(0.0)$ & $2(7.4)$ & $8(50.0)$ & \\
\hline Stromal mitosis & & & & & $<0.001$ \\
\hline $0-4 / 10$ HPFs & $152(78.4)$ & $151(100.0)$ & $1(3.7)$ & $0(0.0)$ & \\
\hline 5-9/ 10 HPFs & $31(16.0)$ & $0(0.0)$ & $26(96.3)$ & $5(31.2)$ & \\
\hline$\geq 10 / 10 \mathrm{HPFs}$ & $11(5.7)$ & $0(0.0)$ & $0(0.0)$ & $11(68.8)$ & \\
\hline Stromal overgrowth & & & & & $<0.001$ \\
\hline Absent & $177(91.2)$ & $151(100.0)$ & $24(88.9)$ & $2(12.5)$ & \\
\hline Present & $17(8.8)$ & $0(0.0)$ & $3(11.1)$ & $14(87.5)$ & \\
\hline Tumor margin & & & & & $<0.001$ \\
\hline Circumscribed & $174(89.7)$ & $148(98.0)$ & $20(74.1)$ & $6(89.7)$ & \\
\hline Infiltrative & $20(10.3)$ & $3(2.0)$ & $7(25.9)$ & $10(62.5)$ & \\
\hline Surgical procedure & & & & & $<0.001$ \\
\hline Local excision & $146(75.3)$ & $131(86.8)$ & $14(51.9)$ & $1(6.2)$ & \\
\hline Wide excision & $34(17.5)$ & $13(8.6)$ & $12(44.4)$ & $9(56.2)$ & \\
\hline Mastectomy & $14(7.2)$ & $7(4.6)$ & $1(3.7)$ & $6(37.5)$ & \\
\hline Radiation therapy & & & & & 0.989 \\
\hline No & $171(88.1)$ & $133(88.1)$ & $24(88.9)$ & $14(87.5)$ & \\
\hline Yes & $23(11.9)$ & $18(11.9)$ & $3(11.1)$ & $2(12.5)$ & \\
\hline Tumor recurrence & $18(9.3)$ & $5(3.3)$ & $6(22.2)$ & $7(43.8)$ & $<0.001$ \\
\hline Distant metastasis & $8(4.1)$ & $0(0.0)$ & $1(3.7)$ & $7(43.8)$ & $<0.001$ \\
\hline
\end{tabular}

PT, Phyllodes Tumor; HPFs, high-power fields 
Board of Yonsei University Severance Hospital. All tissues were fixed in $10 \%$ buffered formalin and embedded in paraffin. All archival hematoxylin and eosin (H\&E)-stained slides for each case were reviewed by 2 pathologists (JS Koo and W Jung). The histologic grade of PT was determined using the H\&E-stained slides according to the WHO classification system [2]. Clinical factors including patients' ages, tumor recurrence, distant metastasis, and survival were collected via review of electronic medical records.

Tissue microarray. A representative area of each $\mathrm{H} \& \mathrm{E}$-stained tumor slide was selected and the corresponding spot was marked on the surface of the corresponding paraffin block. Using a biopsy needle, the selected area was punched out and a $5 \mathrm{~mm}$ tissue core was placed in a $5 \times 6$ recipient block. Two tissue cores were extracted to minimize extraction bias. Each separate tissue core was assigned a unique tissue microarray location number that was linked to a database including other clinical-pathologic data.

Immunohistochemistry. The antibodies used for immunohistochemistry in this study are shown in Table 1 .
All immunostainings were performed using formalin-fixed, paraffin-embedded tissue sections. Briefly, $5-\mu \mathrm{m}$-thick sections were created with a microtome, transferred onto adhesive slides, and dried at $62^{\circ} \mathrm{C}$ for $30 \mathrm{~min}$. After incubation with primary antibodies, immunodetection was performed with biotinylated anti-mouse secondary immunoglobulin, followed by incubation with peroxidaselabeled streptavidin using a labeled streptavidin biotin kit with 3,3'-diaminobenzidine chromogen as the substrate. The primary antibody incubation step was omitted in the negative control. Slides were counterstained with Harris hematoxylin. All immunohistochemical markers were accessed via light microscopy. The proportion of positively stained cells on each slide was graded as 0,1 , and 2, corresponding to negative, positive in fewer than $30 \%$ of tumor cells, and positive in $30 \%$ or more of tumor cells, respectively. The immunostaining intensity was graded as $0,1,2$, or 3, corresponding to negative, weak, moderate, or strong staining, respectively. The results were ultimately scored by

Table 3. Expression of proteins related to lipid metabolism related proteins according to phyllodes tumor grade

\begin{tabular}{|c|c|c|c|c|c|}
\hline $\begin{array}{l}\text { Immunohistochemistry } \\
\text { results }\end{array}$ & $\begin{array}{c}\text { Total } \\
\mathrm{N}=194(100 \%)\end{array}$ & $\begin{array}{c}\mathrm{PT} \\
\text { Benign } \\
\mathrm{N}=151(100 \%)\end{array}$ & $\begin{array}{l}\text { PT, Borderline } \\
\mathrm{N}=27(100 \%)\end{array}$ & $\begin{array}{l}\text { PT, Malignant } \\
\mathrm{N}=16(100 \%)\end{array}$ & $P$-value \\
\hline $\operatorname{HSL}(\mathrm{E})^{*}$ & & & & & 0.951 \\
\hline Negative & $124(67.4)$ & $102(67.5)$ & $17(65.4)$ & $5(71.4)$ & \\
\hline Positive & $60(32.6)$ & $49(32.5)$ & $9(34.6)$ & $2(28.6)$ & \\
\hline HSL (S) & & & & & 0.001 \\
\hline Negative & $147(75.8)$ & $123(81.5)$ & $17(63.0)$ & $7(43.8)$ & \\
\hline Positive & $47(24.2)$ & $28(18.5)$ & $10(37.0)$ & $9(56.2)$ & \\
\hline Perilipin $2(\mathrm{E})^{*}$ & & & & & 0.289 \\
\hline Negative & $136(73.9)$ & $115(76.2)$ & $16(61.5)$ & $5(71.4)$ & \\
\hline Positive & $48(26.1)$ & $36(23.8)$ & $10(38.5)$ & $2(28.6)$ & \\
\hline Perilipin 2 (S) & & & & & $<0.001$ \\
\hline Negative & 189 (97.4) & $151(100.0)$ & $26(96.3)$ & $12(75.0)$ & \\
\hline Positive & $5(2.6)$ & $0(0.0)$ & $1(3.7)$ & $4(25.0)$ & \\
\hline FABP4 (S) & & & & & $<0.001$ \\
\hline Negative & $155(79.9)$ & $133(88.1)$ & $18(66.7)$ & $4(25.0)$ & \\
\hline Positive & $39(20.1)$ & $18(11.9)$ & $9(33.3)$ & $12(75.0)$ & \\
\hline CPT-1 $(\mathrm{E})^{*}$ & & & & & 0.485 \\
\hline Negative & $158(85.9)$ & $128(84.8)$ & $23(88.5)$ & $7(100.0)$ & \\
\hline Positive & $26(14.1)$ & $23(15.2)$ & $3(11.5)$ & $0(0.0)$ & \\
\hline CPT-1 (S) & & & & & 0.034 \\
\hline Negative & $169(87.1)$ & $136(90.1)$ & $22(81.5)$ & $11(68.8)$ & \\
\hline Positive & $25(12.9)$ & $15(9.9)$ & $5(18.5)$ & $5(31.2)$ & \\
\hline FASN $(E)^{*}$ & & & & & 0.625 \\
\hline Negative & $163(88.6)$ & $133(88.1)$ & $23(88.5)$ & $7(100.0)$ & \\
\hline Positive & $21(11.4)$ & $18(11.9)$ & $3(11.5)$ & $0(0.0)$ & \\
\hline FASN (S) & & & & & $<0.001$ \\
\hline Negative & $190(97.9)$ & $151(100.0)$ & $27(100.0)$ & $12(75.0)$ & \\
\hline Positive & $4(2.1)$ & $0(0.0)$ & $0(0.0)$ & $4(25.0)$ & \\
\hline
\end{tabular}

${ }^{*}$ Ten tumors without an epithelial component were excluded. E, epithelial component; $S$, stromal component Bold numbers represent statistically significant results $(\mathrm{p}<0.05)$. 
multiplying the score for proportion of stained cells by the score for staining intensity. Tumors with score of 0 - 1 were counted as negative, and tumors with a score of 2-6 were counted as positive [13].

Statistical analysis. Data were analyzed using SPSS for Windows, Version 12.0 (SPSS Inc., Chicago, IL, USA). To determine statistical significance, Student's $t$ - and Fisher's exact tests were used for continuous and categorical variables, respectively. Statistical significance was assigned if $p<0.05$. Kaplan-Meier survival curves and log-rank statistics were employed to evaluate time to tumor recurrence. Multivariate regression analysis was performed using a Cox proportional hazards model.

\section{Results}

Basal characteristics of phyllodes tumors. The basal characteristics of 194 total patients with PT are summarized in Table 2. Overall, 151, 27, and 16 were diagnosed with benign, borderline, or malignant PT, respectively. Patient age and tumor size increased with greater tumor grade $(p=0.017$, and $p=0.001$, respectively), and the rate of tumor recurrence and distance metastasis also increased with greater tumor grade $(p<0.001)$. The site of metastasis was the lung in every instance of metastatic disease.

Expression of lipid metabolism-related proteins according to phyllodes tumor grade. The expression of lipid metabolism-related proteins was analyzed according to PT grade (Table 3). The expression of HSL, perilipin 2, FABP4, CPT-1, and fatty acid synthase (FASN) in the stromal component was higher in higher grade PTs $(p<0.05$, Figure 1). FABP4 was not expressed in the epithelial component, and ACOX-1 expression was undetectable in both the epithelial and stromal components.

Correlations between the expression of lipid metabolism-related proteins in phyllodes tumor and pathologic parameters. Correlations between the expression of lipid metabolism-related proteins in phyllodes tumor and patho-

Table 4. Univariate analysis of expression of lipid metabolism related proteins with respect to patient prognosis using the log-rank test

\begin{tabular}{|c|c|c|c|c|c|}
\hline \multirow[t]{2}{*}{ Parameters } & \multirow{2}{*}{$\begin{array}{c}\text { No. of patients } \\
\text { Total/recurrence/metastasis }\end{array}$} & \multicolumn{2}{|c|}{ Disease-free survival } & \multicolumn{2}{|c|}{ Overall survival } \\
\hline & & $\begin{array}{l}\text { Median survival } \\
(95 \% \mathrm{CI}) \text { months }\end{array}$ & $P$-value & $\begin{array}{l}\text { Median survival } \\
(95 \% \mathrm{CI}) \text { months }\end{array}$ & $P$-value \\
\hline $\operatorname{HSL}(\mathrm{E})^{*}$ & & & 0.384 & & 0.865 \\
\hline Negative & $124 / 12 / 2$ & $160(152-169)$ & & $174(170-178)$ & \\
\hline Positive & $60 / 3 / 1$ & $173(163-184)$ & & $180(174-185)$ & \\
\hline HSL (S) & & & 0.233 & & 0.836 \\
\hline Negative & $147 / 12 / 6$ & $168(160-176)$ & & $175(170-181)$ & \\
\hline Positive & $47 / 6 / 2$ & $147(125-169)$ & & $167(158-177)$ & \\
\hline Perilipin $2(\mathrm{E})^{*}$ & & & 0.445 & & 0.088 \\
\hline Negative & $136 / 10 / 1$ & $166(158-173)$ & & $177(175-180)$ & \\
\hline Positive & $48 / 5 / 2$ & $163(147-179)$ & & $173(161-186)$ & \\
\hline Perilipin 2 (S) & & & $<0.001$ & & $<0.001$ \\
\hline Negative & $189 / 15 / 5$ & $168(161-175)$ & & $178(174-182)$ & \\
\hline Positive & $5 / 3 / 3$ & $50(0-106)$ & & $62(10-114)$ & \\
\hline FABP4 (S) & & & 0.096 & & $<0.001$ \\
\hline Negative & $178 / 15 / 4$ & $167(160-175)$ & & $179(175-182)$ & \\
\hline Positive & $16 / 3 / 4$ & $110(86-135)$ & & $92(56-128)$ & \\
\hline CPT-1 $(\mathrm{E})^{*}$ & & & 0.940 & & $\mathrm{~N} / \mathrm{A}$ \\
\hline Negative & $158 / 13 / 3$ & $168(160-175)$ & & $\mathrm{N} / \mathrm{A}$ & \\
\hline Positive & $26 / 2 / 0$ & $101(90-111)$ & & $\mathrm{N} / \mathrm{A}$ & \\
\hline CPT-1 (S) & & & 0.004 & & 0.028 \\
\hline Negative & $169 / 12 / 5$ & $170(163-177)$ & & $177(173-182)$ & \\
\hline Positive & $25 / 6 / 3$ & $85(68-101)$ & & $97(85-109)$ & \\
\hline $\operatorname{FASN}(\mathrm{E})^{*}$ & & & $\mathrm{~N} / \mathrm{A}$ & & $\mathrm{N} / \mathrm{A}$ \\
\hline Negative & $163 / 15 / 3$ & $\mathrm{~N} / \mathrm{A}$ & & $\mathrm{N} / \mathrm{A}$ & \\
\hline Positive & $21 / 0 / 0$ & $\mathrm{~N} / \mathrm{A}$ & & $\mathrm{N} / \mathrm{A}$ & \\
\hline FASN (S) & & & 0.140 & & $<0.001$ \\
\hline Negative & $190 / 17 / 6$ & $166(159-174)$ & & $177(172-181)$ & \\
\hline Positive & $4 / 1 / 2$ & $28(15-41)$ & & $23(10-35)$ & \\
\hline
\end{tabular}

*Ten tumors without an epithelial component were excluded. E, epithelial component; S, stromal component Bold numbers represent statistically significant results $(\mathrm{p}<0.05)$. 


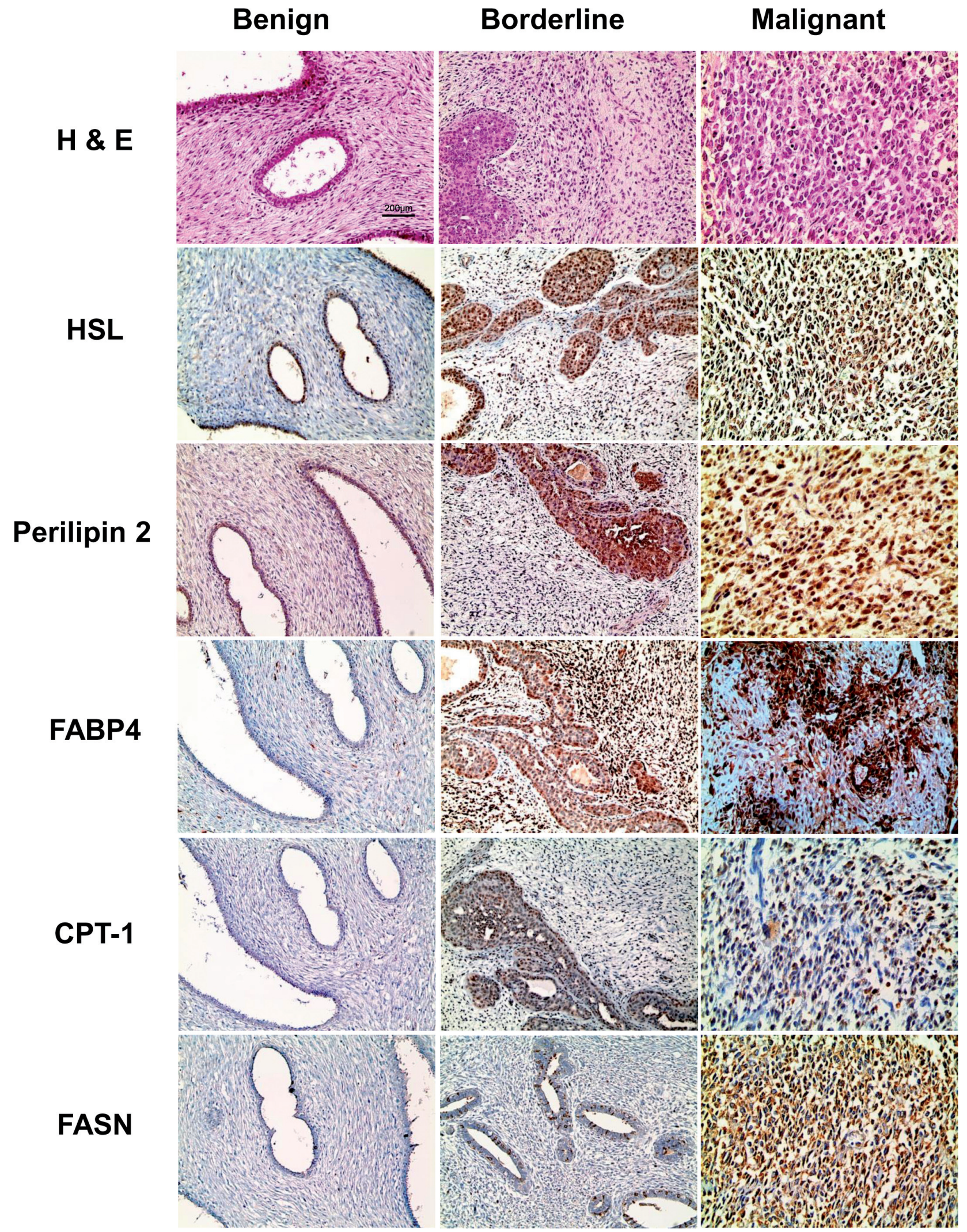

Figure 1. Expression of lipid metabolism-related proteins according to histologic grade of phyllodes tumor (x 200). Higher expression of HSL, perilipin 2, FABP4, CPT-1, and FASN in the stromal component was noted in higher grade PTs. 
logic parameters were evaluated (Figure 2). The factors that were associated with increased stromal cellularity, increased stromal mitosis, and infiltrative tumor margin were stromal perilipin A expression and stromal FABP4 expression $(p<0.05)$; in addition, increased stromal atypia correlated with stromal perilipin A expression $(p=0.001)$. The factors associated with stromal overgrowth included stromal perilipin A expression $(p<0.001)$, stromal FABP4 expression $(p<0.001)$, and stromal FASN expression $(p<0.001)$.

Impact of the expression of lipid metabolism-related proteins on patients' prognoses. A univariate analysis of the impact of expression of lipid metabolism-related proteins on patient prognosis was performed. Shorter disease-free survival (DFS) was associated with stromal perilipin 2 positivity $(p<0.001)$, and stromal CPT-1 positivity $(p=0.004)$, whereas shorter overall survival (OS) was associated with stromal perilipin 2 positivity $(p<0.001)$, stromal FABP 4 positivity $(p<0.001)$, stromal CPT-1 positivity $(p=0.004)$, and stromal FASN positivity $(p<0.001)$ (Table 4 and Figure 3$)$. On a multivariate Cox analysis, the independent predictive factors of shorter DFS included higher histologic grade (hazard ratio $=8.037,95 \%$ CI: $2.024-31.90, p<0.001)$, stromal overgrowth (hazard ratio $=18.501,95 \%$ CI: $2.299-148.8, p=0.006$ ) and stromal perilipin 2 positivity (hazard ratio $=31.693,95 \%$ CI: 1.341-748.8, $p=0.032$ ). Stromal overgrowth was an independent factor of shorter OS (hazard ratio $=93.583,95 \%$ CI: 3.209-2728, $p=0.008$ ) (Table 5).

\section{Discussion}

The present study investigated the expression of lipid metabolism-related proteins in breast PTs. In higher grade PTs, the expression of HSL, perilipin 2, FABP4, CPT-1, and FASN was higher in the stromal component. There is no previous study regarding lipid metabolism-related proteins in PTs to which a direct comparison can be made. However, previous studies have reported that perilipin 2 is expressed in a proportion of sebaceous carcinomas [14], that FABP4 is associated with cancer progression $[15,16]$, and that CPT- 1 is an important factor in cancer cell survival $[17,18]$. In addition, FASN is reported to be involved in tumor progression in various types of neoplasms $[19,20]$, and these facts suggest that lipid metabolism-related proteins play important roles in tumor growth and progression. The metabolism of PT has not been well investigated so far, but in previous studies, the expression of glycolysis-related proteins and serine/glycine metabolism-related proteins were higher in higher grade PTs [11, 12], suggesting increased metabolic activity and increased lipid metabolism occur in higher grade PTs. One possible explanation of the differences in metabolic activity according to PT grade is the association between stem cells and metabolism. In previous studies, metabolic enzymes have been reported to affect cancer stemness [21], of which the epithelialmesenchymal transition (EMT) process has been reported to be an important feature. In this process, the expression of pyruvate kinase muscle isozyme 2 (PKM2) increases, and it

Table 5. Multivariate analysis of disease-free survival in patients with phyllodes tumors

\begin{tabular}{|c|c|c|c|c|c|c|}
\hline \multirow[t]{2}{*}{ Included factor } & \multicolumn{3}{|c|}{ Disease-free survival } & \multicolumn{3}{|c|}{ Overall survival } \\
\hline & Hazard ratio & $95 \% \mathrm{CI}$ & $P$-value & Hazard ratio & $95 \%$ CI & $P$-value \\
\hline Histologic grade & & & $<0.001$ & & & N/A \\
\hline Benign vs. Borderline or Malignant & 8.037 & $2.024-31.90$ & & N/A & N/A & \\
\hline Stromal cellularity & & & 0.243 & & & 0.977 \\
\hline Mild vs. moderate or marked & 0.151 & $0.006-3.597$ & & 1.062 & $0.019-60.74$ & \\
\hline Stromal atypia & & & 0.274 & & & 0.987 \\
\hline Mild vs. moderate or marked & 0.215 & $0.014-3.389$ & & 1.024 & $0.058-18.04$ & \\
\hline Stromal mitosis & & & 0.933 & & & 0.212 \\
\hline $0-4 / 10 \mathrm{HPFs}$ vs. $>4 / 10 \mathrm{HPFs}$ & 1.153 & $0.042-31.95$ & & 0.064 & $0.001-4.763$ & \\
\hline Stromal overgrowth & & & 0.006 & & & 0.008 \\
\hline Absent vs. Present & 18.501 & $2.299-148.8$ & & 93.583 & $3.209-2728$ & \\
\hline Tumor margin & & & 0.087 & & & 0.118 \\
\hline Circumscribed vs. Infiltrative & 0.215 & $0.037-1.250$ & & 0.138 & $0.011-1.658$ & \\
\hline Perilipin $2(S)$ & & & 0.032 & & & 0.080 \\
\hline Negative vs. Positive & 31.693 & $1.341-748.8$ & & 35.677 & $0.651-1956$ & \\
\hline FABP4 (S) & & & 0.483 & & & 0.817 \\
\hline Negative vs. Positive & 0.536 & $0.094-3.062$ & & 1.332 & $0.118-15.07$ & \\
\hline CPT-1 (S) & & & 0.476 & & & 0.338 \\
\hline Negative vs. Positive & 1.671 & $0.407-6.858$ & & 3.450 & $0.274-43.37$ & \\
\hline FASN (S) & & & 0.881 & & & 0.318 \\
\hline Negative vs. Positive & 0.804 & $0.046-14.08$ & & 4.050 & $0.260-63.05$ & \\
\hline
\end{tabular}

S, stromal component

Bold numbers represent statistically significant results $(\mathrm{p}<0.05)$. 

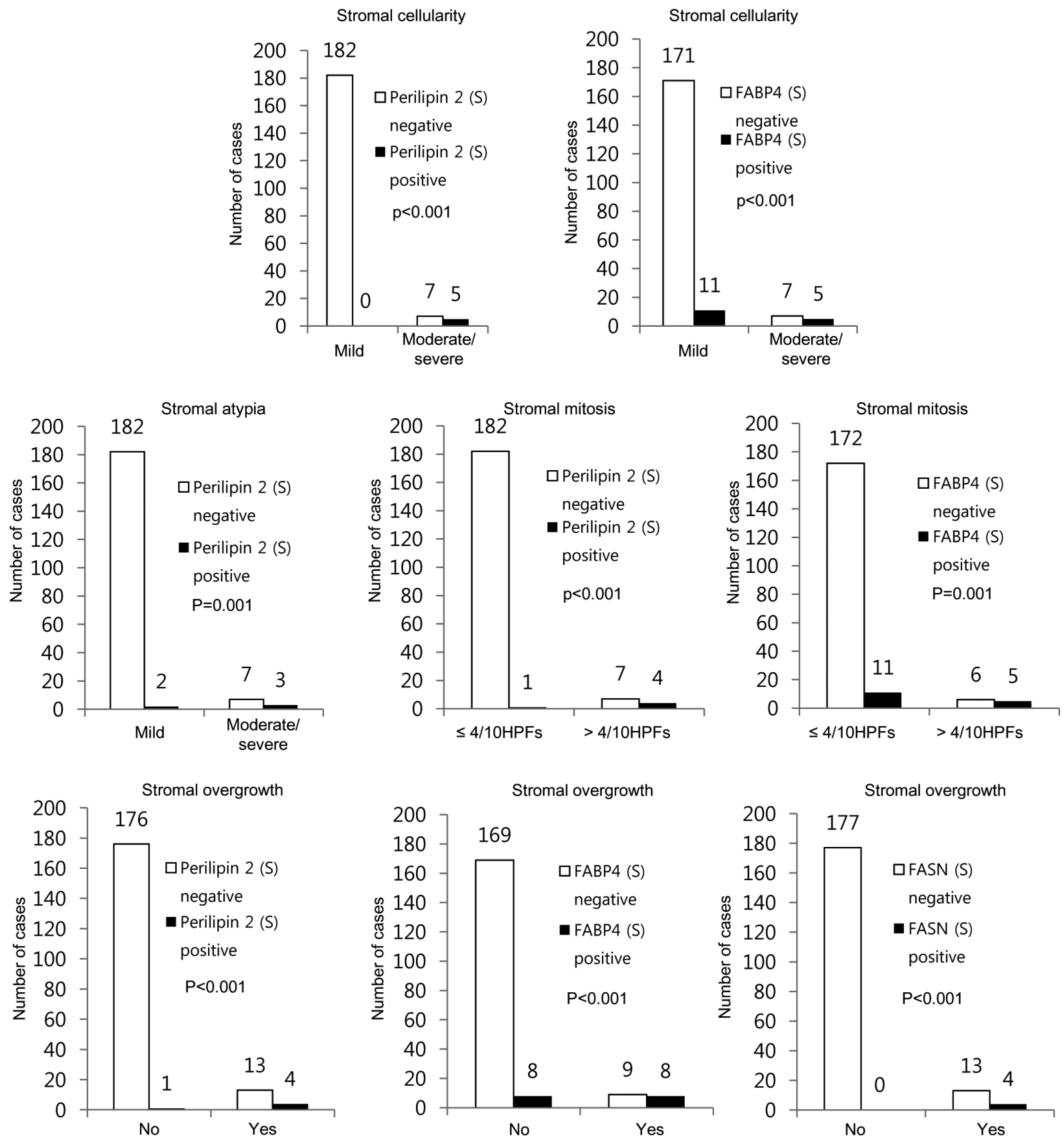

Figure 2. Correlation between the expression of lipid metabolism-related proteins in phyllodes tumor and pathologic parameters. S, stromal component

translocates to the nucleus and interacts with TGFB-Induced Factor Homeobox 2 (TGIF2) and controls the EMT. PKM2 is a key protein in glycolysis in cancer cells, which suggests an association between metabolic enzymes and cancer stemness. Malignant PTs can contain heterologous tumor cell types of stromal origin, such as rhabdomyosarcoma, liposarcoma, and osteosarcoma, suggesting a role for mesenchymal stem cells in PT development. It has also been reported that malignant PTs express elevated levels of aldehyde dehydrogenase (ALDH) and disialoganglioside (GD2), which are characteristic of mesenchymal stem cells [22]. Further study is required to elucidate connections between mesenchymal stem cells and lipid metabolism.

In the present study, perilipin 2 was an independent prognostic factor, and in previous studies, it has been reported to be a prognostic factor in clear cell renal cell carcinoma [23, 24], suggesting its role as a tumor prognostic marker. The clinical implication of the differences observed in lipid metabolism-re- 

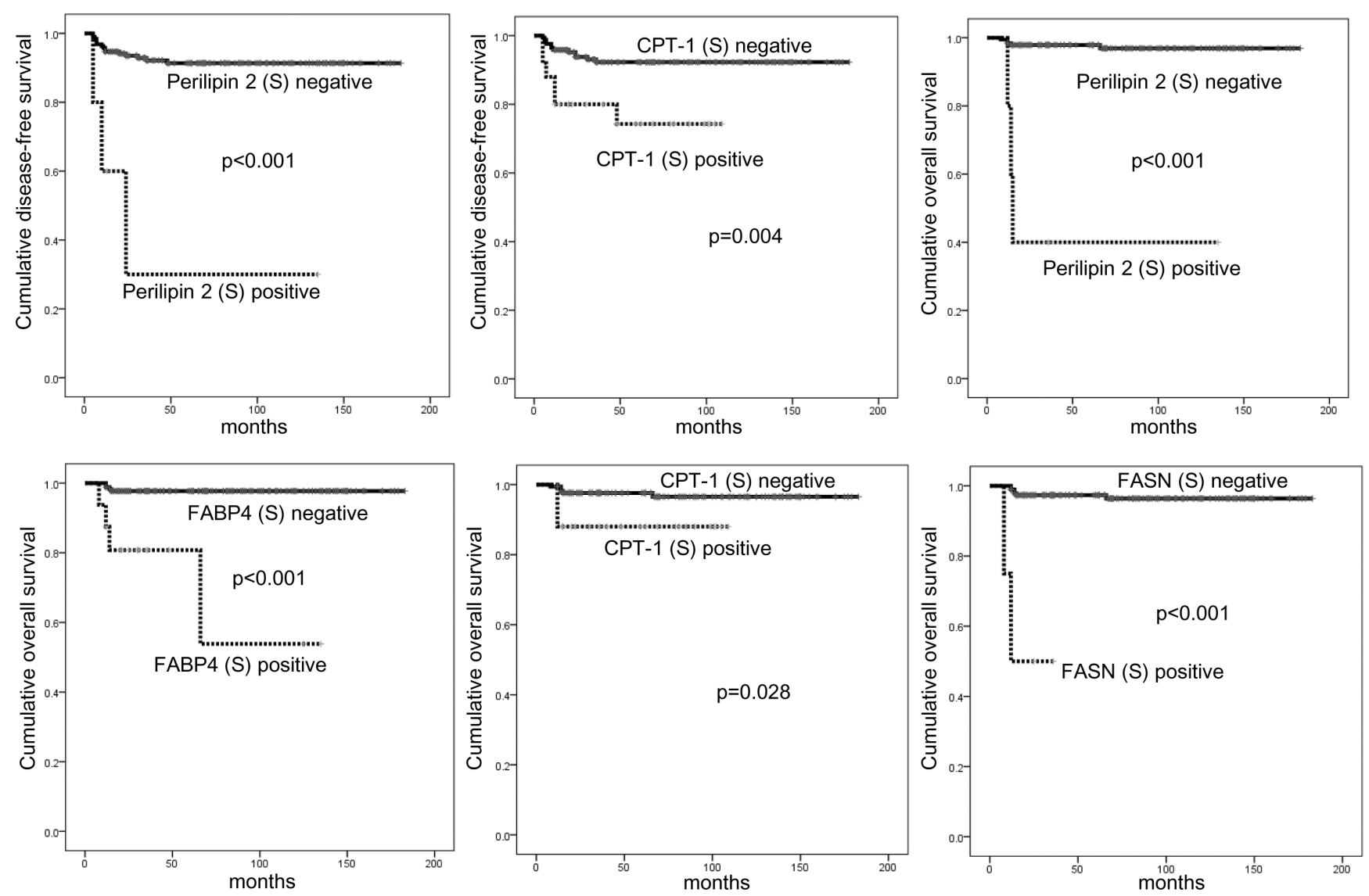

Figure 3. Disease-free survival (a, b) and overall survival (c, d, e, f) according to the status of lipid metabolism-related proteins in phyllodes tumors. S, stromal component

lated protein expression according to PT grade is the potential for lipid metabolism-related proteins to serve as therapeutic targets. Supporting this idea, inhibitors of glycolysis-related molecules such as HIF-1a [25, 26], Glut1 [27, 28], CAIX [29], and MCT4 [30] have been reported to inhibit tumor growth in preclinical studies of various neoplasms, suggesting that metabolic inhibitors are candidate therapeutic agents. Among lipid metabolism-related proteins, the inhibition of CPT-1 [31] and of FASN [32-34] have been reported to inhibit tumor growth. The results of this study support the validity of this therapeutic strategy, which should be pursued further.

Acknowledgements: This research was supported by the Basic Science Research Program through the National Research Foundation of Korea (NRF) funded by the Ministry of Science, ICT, and Future Planning (2015R1A1A1A05001209).

\section{References}

[1] ANDERSON B, LAWTON T, LEHMAN C, MOE R Phyllodes tumor. In: Morrow M, Osborne C, editors. Disease of the Breast. Philadelphia: Lippincott \& Wilkins, 2004: 991-1006.

[2] TAVASSOLI FA DP World Heath Organization Classification of Tumors. Lyon: IARC Press, 2003.
[3] BEN HASSOUNA J, DAMAK T, GAMOUDI A, CHARGUI R, KHOMSI F et al. Phyllodes tumors of the breast: a case series of 106 patients. Am J Surg 2006; 192: 141-147. http:// dx.doi.org/10.1016/j.amjsurg.2006.04.007

[4] WARBURG O On the origin of cancer cells. Science 1956; 123: 309-314. http://dx.doi.org/10.1126/ science.123.3191.309

[5] MORENO-SANCHEZ R, RODRIGUEZ-ENRIQUEZ S, MARIN-HERNANDEZ A, SAAVEDRA E Energy metabolism in tumor cells. FEBS J 2007; 274: 1393-1418. http:// dx.doi.org/10.1111/j.1742-4658.2007.05686.x

[6] KRAEMER FB, SHEN WJ Hormone-sensitive lipase: control of intracellular tri-(di-)acylglycerol and cholesteryl ester hydrolysis. J Lipid Res 2002; 43: 1585-1594. http://dx.doi. org/10.1194/jlr.R200009-JLR200

[7] GREENBERG AS, EGAN JJ, WEK SA, GARTY NB, BLANCHETTE-MACKIE EJ et al. Perilipin, a major hormonally regulated adipocyte-specific phosphoprotein associated with the periphery of lipid storage droplets. J Biol Chem 1991; 266: 11341-11346.

[8] WEISIGER RA Cytosolic fatty acid binding proteins catalyze two distinct steps in intracellular transport of their ligands. Mol Cell Biochem 2002; 239: 35-43. http://dx.doi. org/10.1023/A:1020550405578 
[9] BONNEFONT JP, DJOUADI F, PRIP-BUUS C, GOBIN S, MUNNICH A et al. Carnitine palmitoyltransferases 1 and 2: biochemical, molecular and medical aspects. Mol Aspects Med 2004; 25: 495-520. http://dx.doi.org/10.1016/j. mam.2004.06.004

[10] KAWAGUCHI A, TSUBOTANI S, SEYAMA Y, YAMAKAWA T, OSUMI T et al. Stereochemistry of dehydrogenation catalyzed by Acyl-CoA oxidase. J Biochem 1980; 88: 1481-1486.

[11] KWON JE, JUNG WH, KOO JS The expression of metabolism-related proteins in phyllodes tumors. Tumour Biol 2013; 34: 115-124. http://dx.doi.org/10.1007/s13277-012-0518-9

[12] KWON JE, KIM DH, JUNG WH, KOO JS Expression of serine and glycine-related enzymes in phyllodes tumor. Neoplasma 2014; 61: 566-578. http://dx.doi.org/10.4149/ neo $2014 \quad 069$

[13] WON KY, KIM GY, KIM YW, SONG JY, LIM SJ Clinicopathologic correlation of beclin-1 and bcl-2 expression in human breast cancer. Hum Pathol 2010; 41: 107-112. http://dx.doi. org/10.1016/j.humpath.2009.07.006

[14] BOUSSAHMAIN C, MOCHEL MC, HOANG MP Perilipin 2nd adipophilin expression in sebaceous carcinoma and mimics. Hum Pathol 2013; 44: 1811-1816. http://dx.doi. org/10.1016/j.humpath.2013.02.003

[15] LEE D, WADA K, TANIGUCHI Y, AL-SHAREEF H, MASUDA T et al. Expression of fatty acid binding protein 4 is involved in the cell growth of oral squamous cell carcinoma. Oncol Rep 2014; 31: 1116-1120. http://dx.doi.org/10.3892/ or.2014.2975

[16] UEHARA H, TAKAHASHI T, OHA M, OGAWA H, IZUMI $\mathrm{K}$ Exogenous fatty acid binding protein 4 promotes human prostate cancer cell progression. Int J Cancer 2014; 135: 2558-2568. http://dx.doi.org/10.1002/ijc.28903

[17] ROTONDO D, DAVIDSON J Genetics and molecular biology: fatty acid metabolism in cancer cell survival; carnitine palmitoyltransferase- 1 as a critical anticancer target. Curr Opin Lipidol 2011; 22: 428-429. http://dx.doi.org/10.1097/ MOL.0b013e32834b0d7f

[18] ZAUGG K, YAO Y, REILLY PT, KANNAN K, KIARASH R et al. Carnitine palmitoyltransferase $1 \mathrm{C}$ promotes cell survival and tumor growth under conditions of metabolic stress. Genes Dev 2011; 25: 1041-1051. http://dx.doi.org/10.1101/ gad.1987211

[19] BAUERSCHLAG DO, MAASS N, LEONHARDT P, VERBURG FA, PECKS U et al. Fatty acid synthase overexpression: target for therapy and reversal of chemoresistance in ovarian cancer. J Transl Med 2015; 13: 146. http://dx.doi.org/10.1186/ s12967-015-0511-3

[20] ZAYTSEVA YY, HARRIS JW, MITOV MI, KIM JT, BUTTERFIELD DA et al. Increased expression of fatty acid synthase provides a survival advantage to colorectal cancer cells via upregulation of cellular respiration. Oncotarget 2015;

[21] KONNO M, DOKI Y, MORI M, ISHII H [Metabolism enzyme controls cancer stemness]. Nihon Rinsho 2015; 73: 745-750.

[22] LIN JJ, HUANG CS, YU J, LIAO GS, LIEN HC et al. Malignant phyllodes tumors display mesenchymal stem cell features and aldehyde dehydrogenase/disialoganglioside identify their tumor stem cells. Breast Cancer Res 2014; 16: R29. http:// dx.doi.org/10.1186/bcr3631

[23] YAO M, HUANG Y, SHIOI K, HATTORI K, MURAKAMI $\mathrm{T}$ et al. Expression of adipose differentiation-related protein: a predictor of cancer-specific survival in clear cell renal carcinoma. Clin Cancer Res 2007; 13: 152-160. http://dx.doi. org/10.1158/1078-0432.CCR-06-1877

[24] YAO M, TABUCHI H, NAGASHIMA Y, BABA M, NAKAIGAWA $\mathrm{N}$ et al. Gene expression analysis of renal carcinoma: adipose differentiation-related protein as a potential diagnostic and prognostic biomarker for clear-cell renal carcinoma. J Pathol 2005; 205: 377-387. http://dx.doi.org/10.1002/path.1693

[25] CHANG H, SHYU KG, LEE CC, TSAI SC, WANG BW et al. GL331 inhibits HIF-1alpha expression in a lung cancer model. Biochem Biophys Res Commun 2003; 302: 95-100. http://dx.doi.org/10.1016/S0006-291X(03)00111-6

[26] YEO EJ, CHUN YS, CHO YS, KIM J, LEE JC et al. YC-1: a potential anticancer drug targeting hypoxia-inducible factor 1. J Natl Cancer Inst 2003; 95: 516-525. http://dx.doi.org/10.1093/ jnci/95.7.516

[27] MOHANTI BK, RATH GK, ANANTHA N, KANNAN V, DAS BS et al. Improving cancer radiotherapy with 2-deoxy-Dglucose: phase I/II clinical trials on human cerebral gliomas. Int J Radiat Oncol Biol Phys 1996; 35: 103-111. http://dx.doi. org/10.1016/S0360-3016(96)85017-6

[28] AFT RL, ZHANG FW, GIUS D Evaluation of 2-deoxy-Dglucose as a chemotherapeutic agent: mechanism of cell death. Br J Cancer 2002; 87: 805-812. http://dx.doi.org/10.1038/ sj.bjc. 6600547

[29] VULLO D, FRANCHI M, GALLORI E, PASTOREK J, SCOZZAFAVA A et al. Carbonic anhydrase inhibitors: inhibition of the tumor-associated isozyme IX with aromatic and heterocyclic sulfonamides. Bioorg Med Chem Lett 2003; 13: 1005-1009. http://dx.doi.org/10.1016/S0960-894X(03)00091-X

[30] GALLAGHER SM, CASTORINO JJ, WANG D, PHILP NJ Monocarboxylate transporter 4 regulates maturation and trafficking of $\mathrm{CD} 147$ to the plasma membrane in the metastatic breast cancer cell line MDA-MB-231. Cancer Res 2007; 67:4182-4189. http://dx.doi.org/10.1158/0008-5472.CAN-06-3184

[31] SCHLAEPFER IR, RIDER L, RODRIGUES LU, GIJON MA, PAC CT et al. Lipid catabolism via CPT1 as a therapeutic target for prostate cancer. Mol Cancer Ther 2014; 13: 2361-2371. http://dx.doi.org/10.1158/1535-7163.MCT-14-0183

[32] JIN Q, YUAN LX, BOULBES D, BAEK JM, WANG YN et al. Fatty acid synthase phosphorylation: a novel therapeutic target in HER2-overexpressing breast cancer cells. Breast Cancer Res 2010; 12: R96. http://dx.doi.org/10.1186/bcr2777

[33] LEE JS, SUL JY, PARK JB, LEE MS, CHA EY et al. Fatty acid synthase inhibition by amentoflavone suppresses HER2/ neu (erbB2) oncogene in SKBR3 human breast cancer cells. Phytother Res 2013; 27: 713-720. http://dx.doi.org/10.1002/ ptr.4778

[34] PUIG T, AGUILAR H, CUFI S, OLIVERAS G, TURRADO $\mathrm{C}$ et al. A novel inhibitor of fatty acid synthase shows activity against HER2 + breast cancer xenografts and is active in antiHER2 drug-resistant cell lines. Breast Cancer Res 2011; 13: R131. http://dx.doi.org/10.1186/bcr3077 